\title{
The Development of Student Grades Information System at SDIT Using Waterfall Model
}

\author{
Adjat Sudradjat \\ Universitas Bina Sarana Informatika \\ Jakarta, Indonesia \\ adjat.ajt@bsi.ca.id
}

\begin{abstract}
As one of the educational institutions, Sekolah Dasar Islam Terpadu (SDIT) must be able to perform the data processing of students' grades well, because it will be used as one of the clear and valid benchmarks to determine student achievement level as learners. The conventional processing system of students' grades requires a lot of time and effort for teachers and administrative staff to write down the marks in ledgers and report books, as well as to recapitulate student grades at the end of the semester. The manual processing of students' grades is also vulnerable to errors that come from inaccuracy in the process, thus affecting the accuracy of data and reduce the level of validity of information generated. The research uses waterfall method to discuss and develop of the student grades information system in Sekolah Dasar Islam Terpadu (SDIT) with the aim to provide convenience in processing the data and accelerate the making of reports of achievement of learning. The scope of discussion is to focus on the management of student personal data, student's grades data, student mutation data, to the results of learning achievements. The research results an application program that manages student grades with a reliable level of data accuracy, parents can obtain valid reports on student achievement, and SDIT stakeholders can receive strategic information for learning evaluation materials and determine future policy in school teaching and learning activities. The development of student grades information systems using waterfall method is able to overcome human errors, so the information generated is maintained its validity. The application can accelerate the student assessment process, so that the level of satisfaction of students, parents and SDIT Principal towards the final results of the learning process is better than before.
\end{abstract}

Keywords - Information System; Student Grades; Waterfall Method

\section{INTRODUCTION}

The quality of superior human resources is an absolute requirement to advance the level of socioeconomic well-being of the community, and one of the important means is education. "A school is a formal education environment. It is said to be formal because in the school a series of planned and organized activities are carried out, including the activities of teaching and learning process in the classroom" (Winkel, 2009). "Schools must be able to look at the needs of varied students, the desires of different education staff, diverse environmental conditions, hopes of the people who entrust their children to schools so that they will be independent, and the demands of the workforce to obtain productive, potential and quality workers" (Mulyasa, 2011). In line with UU No. 20 Tahun 2003 Pasal 17 Sistem Pendidikan Nasional, Sekolah Dasar Islam Terpadu (SDIT) as one of the types of schools in the elementary education level must be able to become a good foundation for stepping on the level of junior high education. For this reason, SDIT must manage all activities of students. "Management of students generally is divided into four important activities, that is: acceptance of students, administration of students, recording of guidance and counseling, and recording of learning achievement" (Arikunto \& Yuliana, 2008). One of benchmarks of the success of SDIT Students education is the learning achievement results reflected in all daily assignment scores and test scores. For this reason, student grades data must be 
processed properly and managed in an integrated manner, so that the information released by the school in the form of reports on student achievement can be accounted for validity.

The student grades data processing system that is done conventionally requires a lot of time and energy for teachers and administrative staff to write down of student grades in leger and report books, and making recapitulation of student grades at the end of each semester. The manual process is also susceptible to errors that originate from inaccuracies during the process, thus affecting the accuracy of the data and reducing the level of validity of the information produced. Although it has used computers to process student grades data, spreadsheet applications such as Microsoft Excel have not been fully effective in helping, because the level of ability of teachers and administrative staff varies in using it. In addition, there are concerns if the file is damaged or lost when the computer has a problem.

The research describes the development of a computerized academic information system in Integrated Islamic Elementary School (SDIT) with a focus on the management of students' personal data, student grades, student mutations, and reports on learning achievement using desktop applications. The purpose of the study is to provide convenience when processing the data to the stage of making reports in a faster time and more accurate results. With the accuracy of the data that can be accounted for, the parents of students will obtain a valid report about the development of their children's learning achievements, and the SDIT Principal can use the report as strategic information for learning evaluation materials and determine further policies in learning and teaching activities in school.

The Researchers Dian Puspita and Eka Yuliana conducted a research on student grades processing at SDN 1 Jayasakti that are still run manually, and they managed to design an application program using visual basic to overcome problems that happen in the manual processes, such as difficulties in making reports, etc. The Users can process the student grades data easily and quickly with high degree of accuracy, and able to produce valid information. But, the designed system needs to be refined, because it runs only for single user and does not have the ability to backup data (Puspita \& Yuliana, 2016).

The Researchers Emil Salim Posungge and Asmawati conducted a research about student grades processing at SMP 2 Bahodopi, and succeeded to develop the information system of student grades with a prototype method to overcome the problem of recording old grades and difficulty in finding previous grades. The application created using visual basic is proven to be able to accelerate the processing of student grades data, facilitate the search for existing data, and facilitate teachers in calculating student grades and making reports. But, the system does not provide data backup facilities, so it needs to be refined (Podungge \& Asmawati, 2017).

The researcher Rino Ramadan conducted a research about student academic activities at SMK Kesehatan Via Medika, and succeeded in developing a web-based academic information system to process data of students, teachers, classes, subjects, teaching and student grades. The process of academic data was previously managed manually, so it requires a long time. The web-based application is proven to be able to accelerate the processing of academic data at SMK Kesehatan Via Medika, because the system has provided various facilities and automated processes that make it easier for users to run it. But the system built also does not provide data backup facilities, even though the information can be accessed online contains important academic data and must be well maintained (Ramadan, 2018).

\section{Literature REviEW}

\subsection{Student Grades Information System}

A system is a group of elements that are interconnected and responsible for the input process so as to produce output. If there is an element that does not contribute at all in a system, it is certain that the element is not part of the system in question (Paryati \& Murya, 2008).

Based on the description above, a system has the following characteristics:

1. A system has a component or element called a subsystem.

2. Has a clear system boundary.

3. Has an outside system environment.

4. There is a system link.

5. Has input, process and output.

6. There are goals or objectives.

Information is data that has been converted into a meaningful and useful context for certain end users (O'Brien, 2006). Quality information has the following criteria:

1. Accurate Information must be free from errors and cannot or be misleading.

2. Just in time

The information provided or data at the recipient may not be late. 
3. Relevant

This information has benefits for the wearer. An information system is said to be valuable if the benefits are more effective than the cost of income.

\section{Complete}

The information sent must be complete so as not to misunderstand.

Student grades information system is an information system designed to help teachers and administrative staff in processing student grades data with the application of desktop applications, so that the process of student assessment activities is easier, faster and with accurate results, so that the information that comes out can be accounted for validity to be conveyed to students and parents as reports on student achievement, as well as to school leaders as material for academic evaluation and as well as determining further policies in the process of learning and teaching in schools.

\subsection{The Integrated Islamic Elementary School}

UU No. 20 Tahun 2003 Pasal 17 Sistem Pendidikan Nasional, defines education as follows:

1. Elementary school education is an education level that underlies the level of secondary education.

2. Elementary school education in the form of elementary schools (SD) and Islamic elementary schools (MI) or other forms that are equal and junior high schools (SMP) and Madrasah Tsanawiyyah (MTs), or other forms of equal.

The concept of the Integrated Islamic Elementary School (SDIT) that emerged in the early period of 2000 was offered as an alternative solution to the restlessness of some Muslim communities who wanted an Islamic education institution committed to practicing Islamic values in a learning system in which not only general learning, but also Islamic religious education which is directly practiced in the process of learning and teaching, so the theory obtained in the classroom can be directly applied in everyday life. This concept is believed to be able to build quality education by integrating various components and forces that are expected to be able to give birth to competitive Indonesian humans and at the same time have high integrity and morality (Akhmad, 2016)

\subsection{Unified Modelling Language}

Unified Modeling Language is a language that has become a standard in the industry for visualizing, designing and documenting software (Yasin, 2012).
According to (Yasin, 2012), several important types of UML diagrams are used to help design the system as follows:

\section{a. Use case Diagram}

Use case diagrams describe the functionality expected of a system. What is emphasized is "what" the system does and not "how". A use case presents interactions between actors and systems. Use case is a particular job, such as logging into the system, creating a shopping list and so on. A person or actor is a human entity or machine that interacts with the system to do work. Use case diagrams can be very helpful when we compile a system's requirements, communicate the design with the client and design a test case for all the features on the system.

\section{b. Activity Diagram}

Activity diagrams describe the various activities in the system that are being designed, how each flow starts, the decisions that may occur and how they end. Activity diagrams can also describe parallel processes that might occur in several executions. Activity diagrams are special state diagrams, most of which are actions and most transitions are triggered by the completion of the previous state (internal processing).

\section{c. Component Diagram}

Component diagrams describe the structure and relationships between software components, including dependencies between them. Component software is a module containing code, both containing source code and binary code, both libraries and executables, both of which appear at compile time, link time and run time. Generally, components are made up of several classes and/or packages, but can also be from smaller components. Components can also be interfaces, namely a collection of services provided by a component for other components.

\section{d. Deployment Diagram}

Deployment diagrams describe the details of how components are deployed in a system infrastructure, where components will be located (on what machine, server or hardware), how the network capabilities at that location, the specifications of server and other things physically.

\subsection{Entity Relationship Diagram}

Entity Relationship Diagrams (ERD) are graphical representations of data for organizations or for business areas, using entities as data categories and relationships for associations between entities (Hoffer, Ramesh, \& Topi, 2011). ERD is a model of data representation and its relationship is clearly what will be used to build a database. Symbolic notations in the ERD (Fathansyah, 2007), including: 
a. Rectangle, declares the set of entities.

b. Circle, declares Attribute (Attribute that functions as a key underlined).

c. Rhombus, states the Association of Relations.

d. The line, as a liaison between the Association of Relations with the Association of Entities and the Set of Entities with their Attributes.

e. Relationship cardinality can be expressed by the number of branch lines or by the use of numbers ( 1 and 1 for one-to-one, 1 and $\mathrm{N}$ relations for oneto-many relations or $\mathrm{N}$ and $\mathrm{N}$ for many-to-many relations).

\section{Proposed Method}

\subsection{Data Collection Technique}

Some data collection techniques that are used in this study are:

\section{A. Observation}

To observe directly on several Integrated Islamic Elementary Schools (SDIT), for getting a complete and clear picture of how to process and manage student grades data that has been going on.

\section{B. Interview.}

To conducted a question and answer session with the homeroom teacher and administration staff at SDIT who were directly involved in processing student grade data.

\section{Library Study}

To seeks and studies several books and other literature to underlie the theories that the author uses in this study.

\subsection{System Development Method}

The waterfall method is used in developing student grades information system for SDIT. The waterfall is a method that is widely used in the development of a software system. The waterfall is a basic process such as specification, development, validation, and representing it as different process phases such as requirements specifications, software design, implementation, testing and so on (Sommerville, 2011).

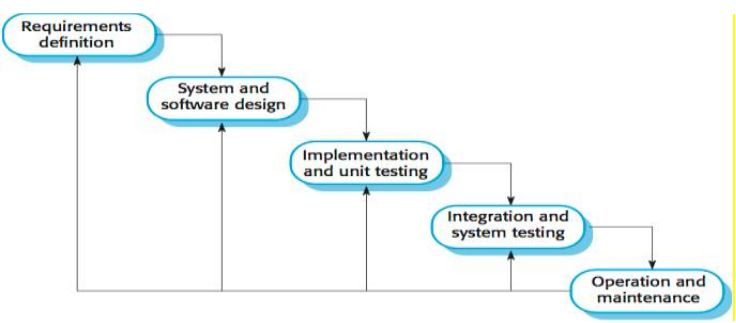

Fig 1. Phases in the Waterfall Method (Sommerville, 2011)
Based on the picture above, here is an explanation of the waterfall phases (Sommerville, 2011):

1. Requirements analysis and definition

Gathering needs in full is then analyzed and defined needs that must be met by the program to be built. This phase must be done in full to be able to produce a complete design.

2. System and software design

The design is done after the needs are completed in full.

3. Implementation and unit testing

Program design is translated into codes using predetermined programming languages. Programs that are built directly are tested in a unit manner.

4. Integration and system testing

Unification of program units is then tested as a whole (system testing).

5. Operation and maintenance

Operate programs in their environment and carry out maintenance, such as adjustments or changes because of adaptation to the actual situation.

\section{RESUlt AND DISCUSSION}

\subsection{Definition and analysis of needs}

Based on observations made at the Integrated Islamic Elementary School, the author defines and analyzes the needs of users, both teachers and administrative staff in the school of information systems to be developed, namely the SDIT student information system value must be able to manage students' personal data, class data, data of signatory officials, process of student grades, the process of moving classes, printing student data reports, class data reports, student grade data reports and database backup processes. With the addition of several Islamic religious subjects as a characteristic of Integrated Islamic Elementary Schools.

\subsection{System and Software Design}

Development of Student Values Information Systems in Integrated Islamic Primary Schools is documented in the following UML and ERD diagrams: 
1. Use case Diagram

a. Use case of Administration Staff

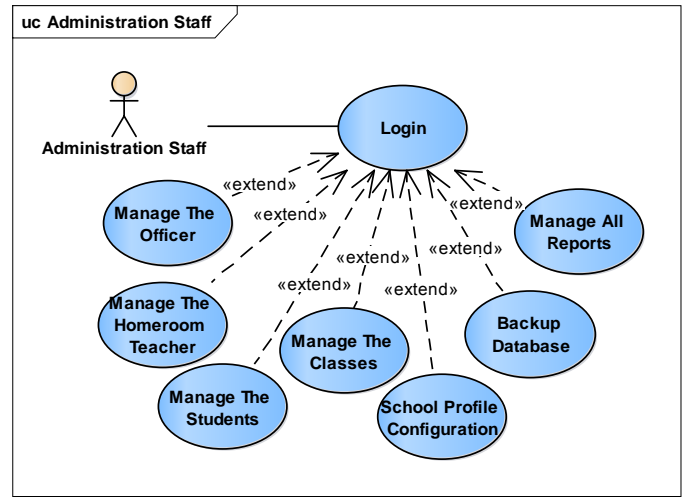

Fig 2. Use case of Administration Staff (Research Results, 2019) b. Use case of Homeroom Teacher

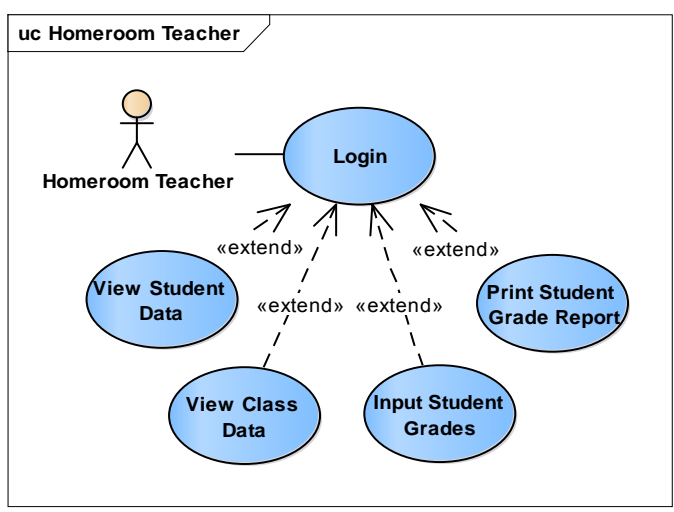

Fig 3. Use case of Homeroom Teacher (Research Results, 2019)

\section{Activity Diagram}

a. Activity Diagram of Master Data Management

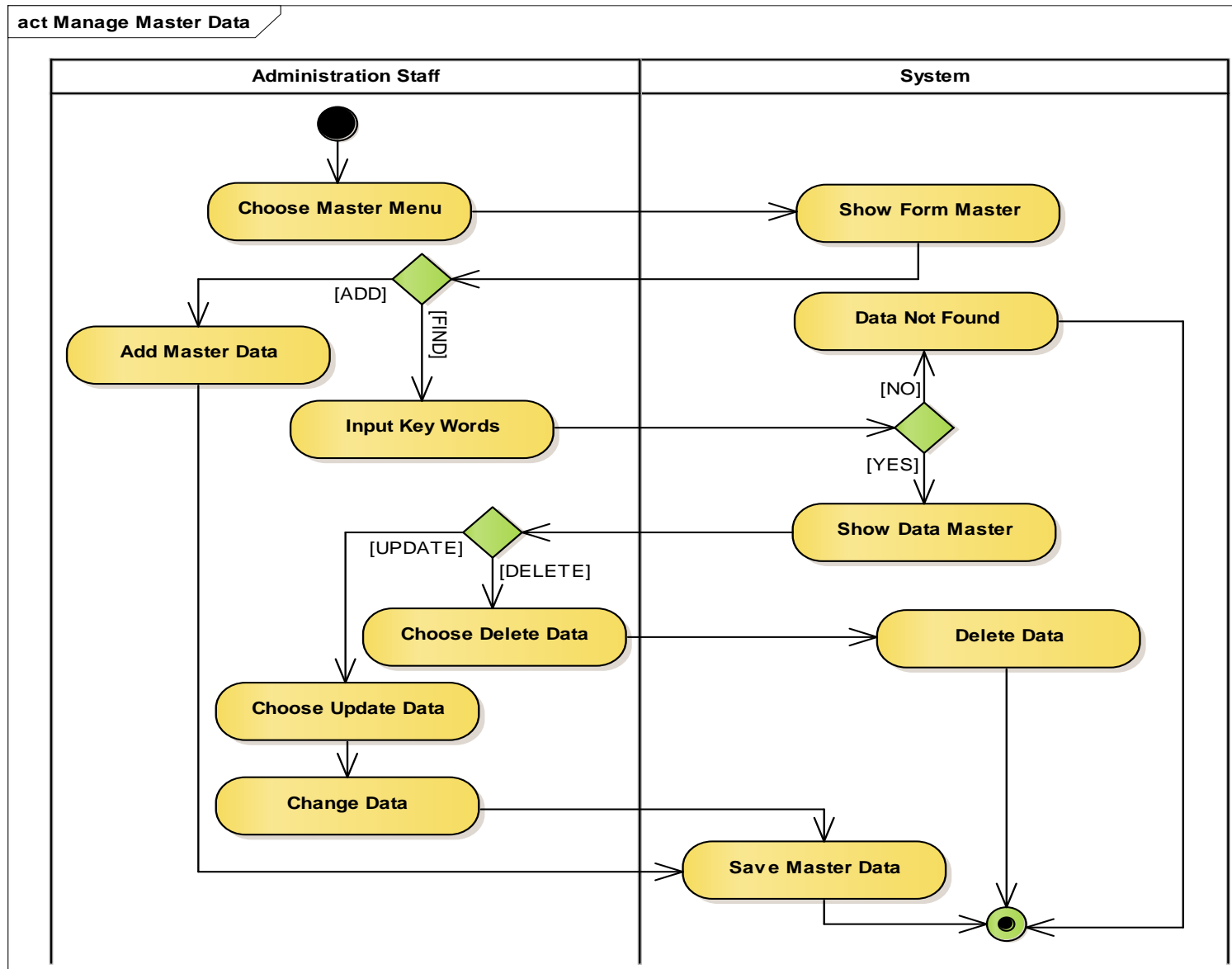

Fig 4. Activity Diagram of Master Data Management (Research Results, 2019) 
b. Activity Diagram of Entry of Student Grade

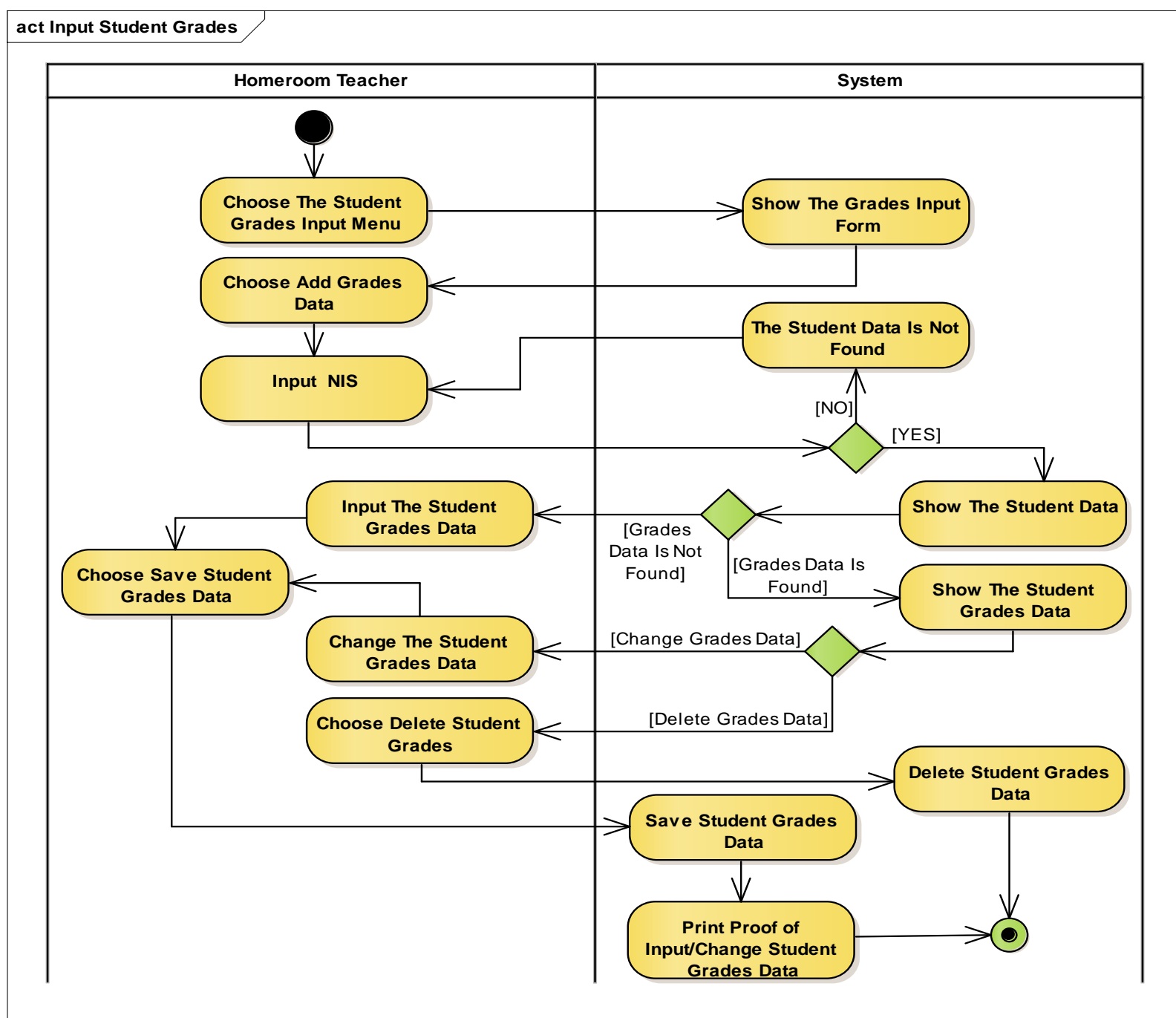

Fig 5. Activity Diagram of Entry of Student Grade (Research Results, 2019)

3. Component Diagram of SI SDIT Student Grades

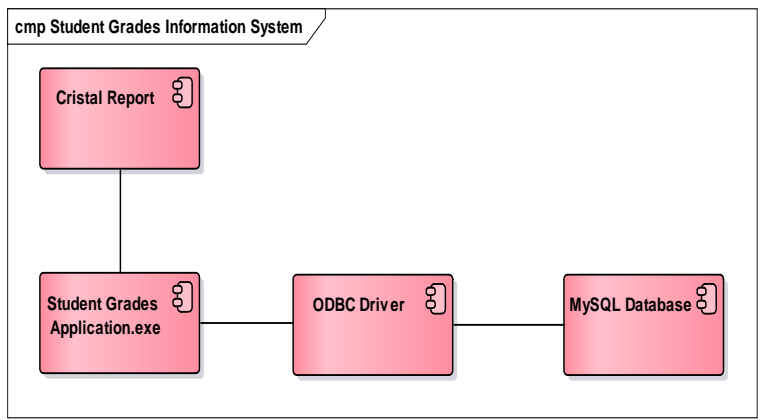

Fig 6. Component Diagram of SI SDIT Student Grades (Research Results, 2019)
4. Deployment Diagram of SI SDIT Student Grades

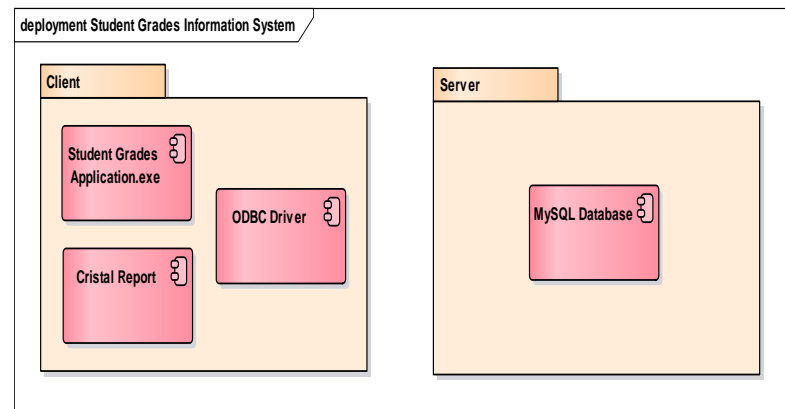

Fig 7. Deployment Diagram of SI SDIT Student Grades (Research Results, 2019) 
5. Entity Relationship Diagram of SI SDIT Student Grades

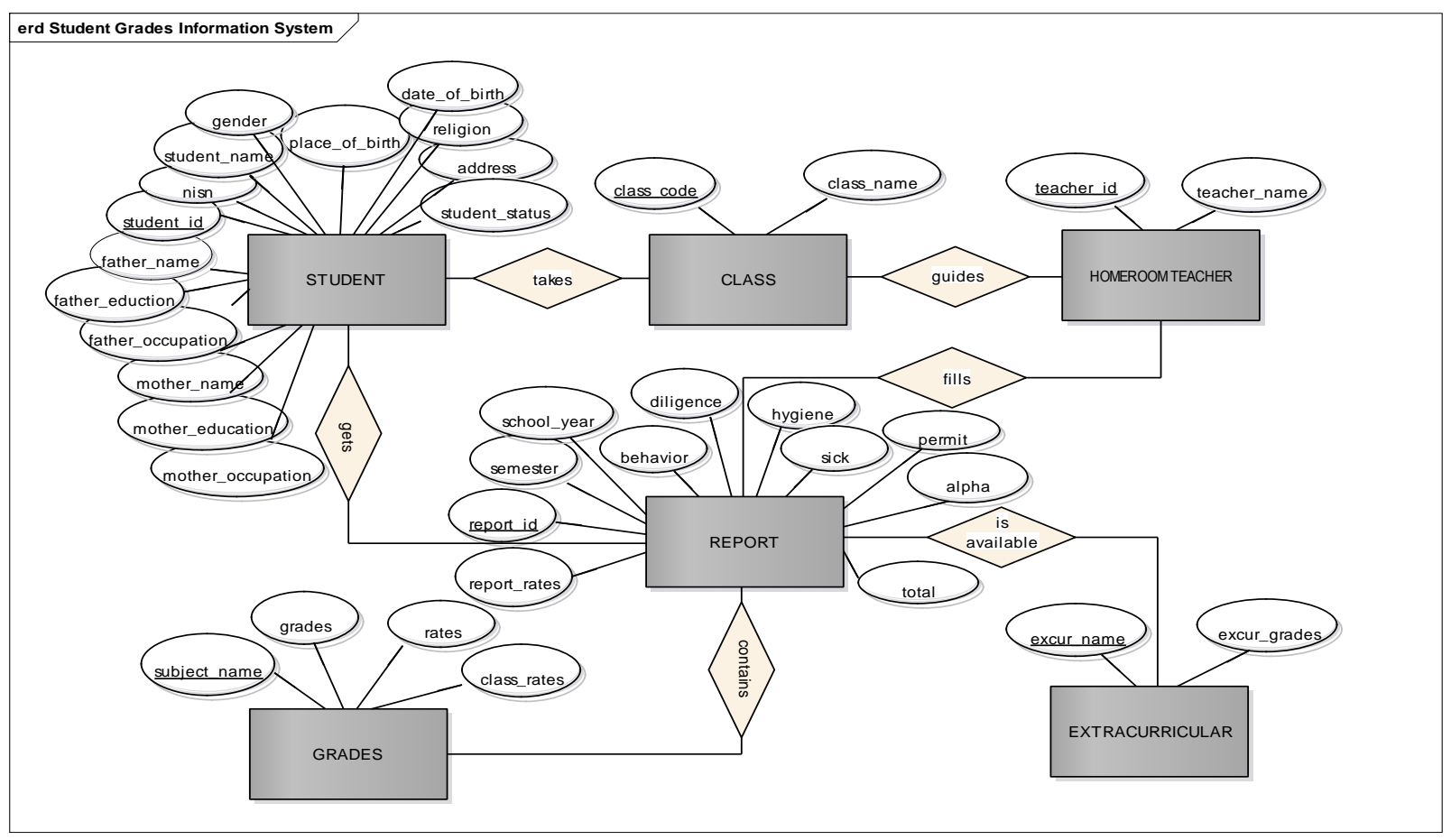

Fig 8. Entity Relationship Diagram of SI SDIT Student Grades (Research Results, 2019)

\subsection{Implementation}

The Design of SDIT Student Grades Information System in the form of UML and ERD diagrams, then implemented into software applications with Visual Basic 6.0 programming language and MySQL database, so that administration staff and homeroom teachers as system actors can test the system and provide input on each module that has been created.

a. Implementation of Interface Display

1. Display Form of Login

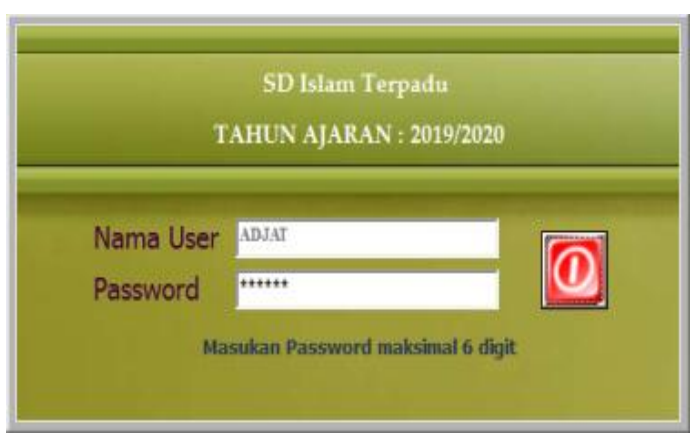

Fig 9. Display Form of Login (Research Results, 2019)
2. Display Form of Main Menu for Administration Staff

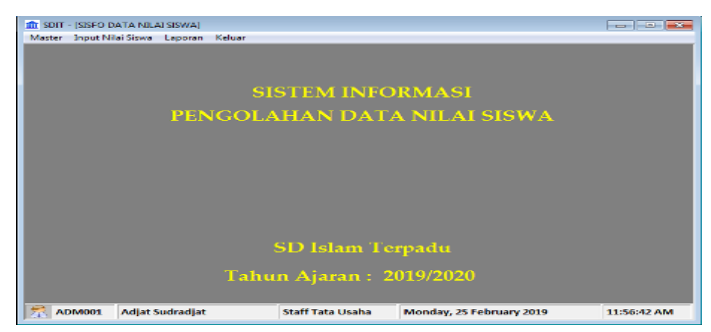

Fig 10. Display Form of Main Menu for Administration Staff (Research Results, 2019)

3. Display Form of Main Menu for Homeroom Teacher

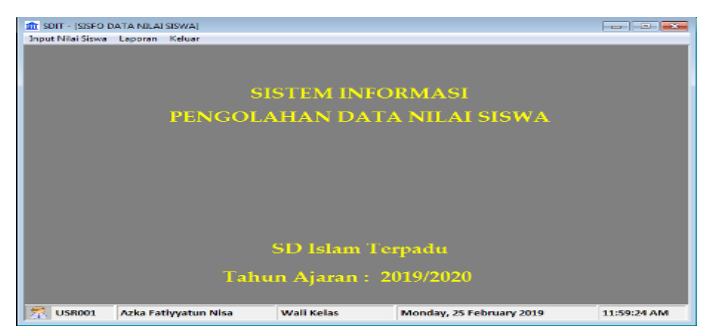

Fig 11. Display Form of Main Menu for Homeroom Teacher (Research Results, 2019) 


\section{Display Form of Class}

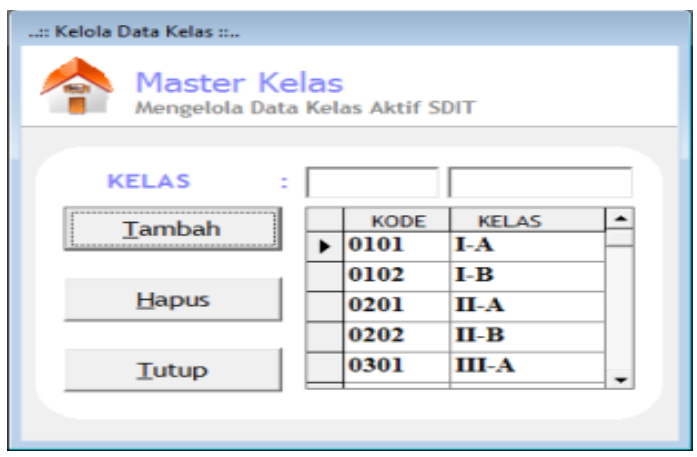

Fig 12. Display Form of Class (Research Results, 2019)

\section{Display Form of Homeroom}

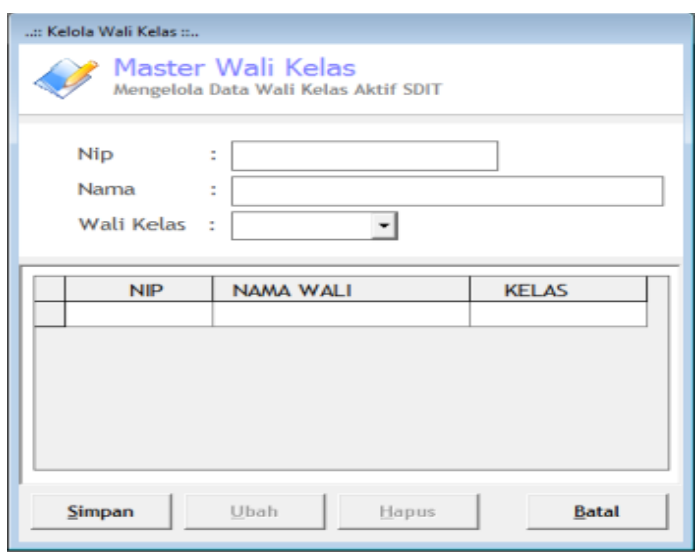

Fig 13. Display Form of Homeroom Teacher (Research Results, 2019)

\section{Display Form of Student}

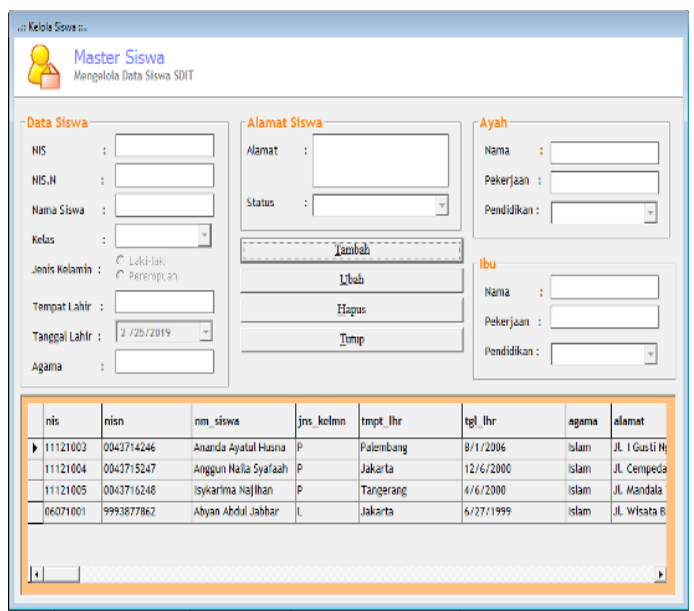

Fig 14. Display Form of Student (Research Results, 2019)
7. Display Form of Student Grade Input

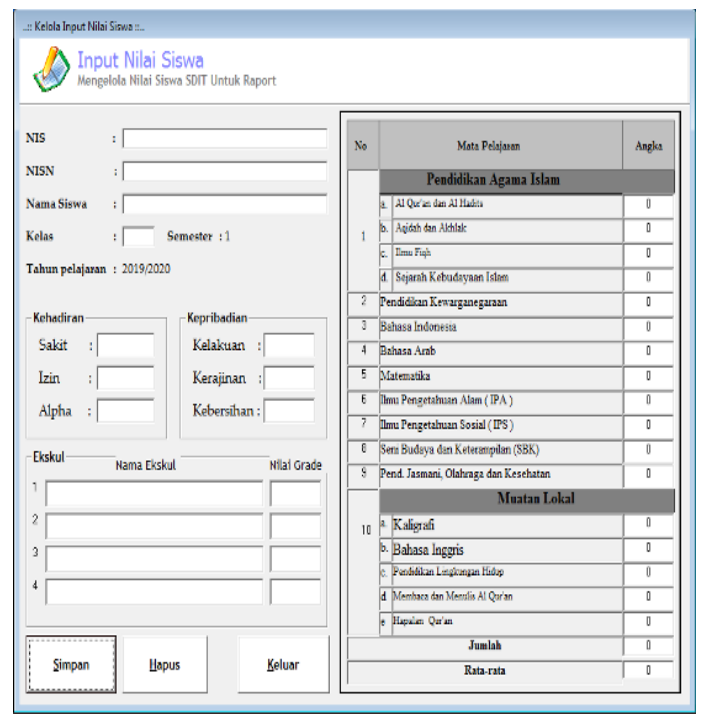

Fig 15. Display Form of Student Grade Input (Research Results, 2019)

8. Display Form of Student Data Searching

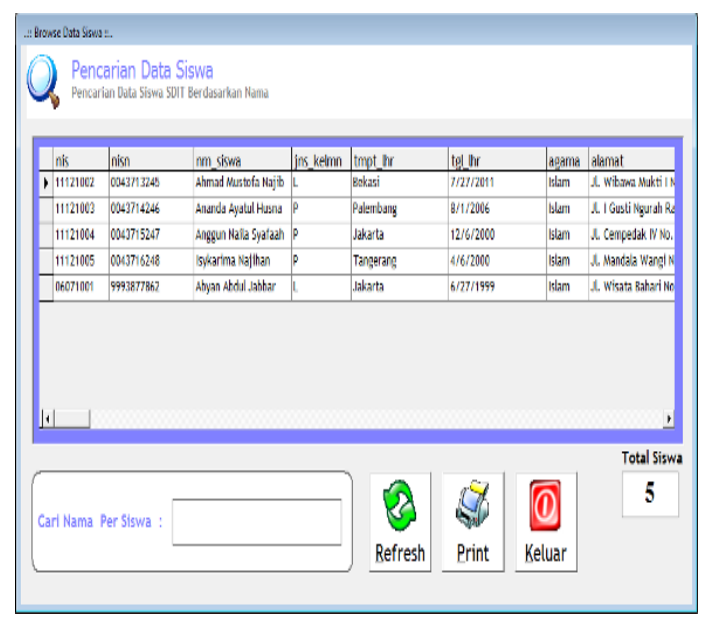

Fig 16. Display Form of Student Data Searching (Research Results, 2019)

9. Display Form of Student Grades Report

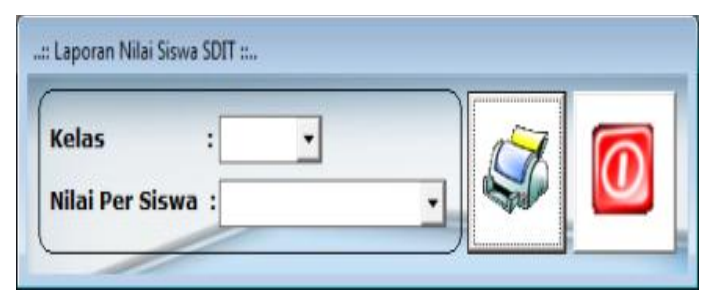

Fig 17. Display Form of Student Grades Report (Research Results, 2019) 
10. Display Form of Backup Database

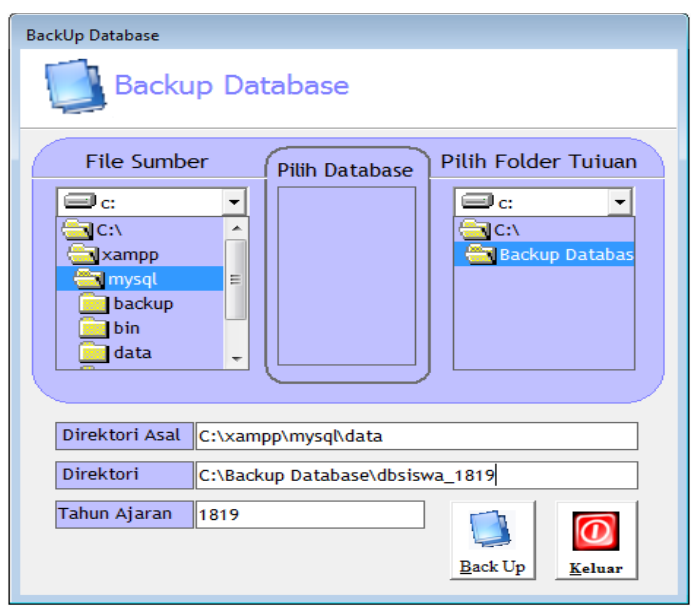

Fig 18. Display Form of Backup Database (Research Results, 2019)

\section{a. Database Implementation}

The dbGradesSDIT database is managed using the MySQL DBMS with table specifications as follows:

\section{Table of Class}

Table 1. The Specification of Class Table

\begin{tabular}{|c|l|l|c|c|c|}
\hline No & $\begin{array}{l}\text { Data } \\
\text { Element }\end{array}$ & Acronym & Type & Len & Info \\
\hline 1 & Class Code & class_code & char & 4 & $P K$ \\
\hline 2 & Class Name & class_name & varchar & 15 & \\
\hline 3 & Teacher ID & teacher_id & char & 18 & $F K$ \\
\hline
\end{tabular}

Source : (Research Results, 2019)

\section{Table of Homeroom Teacher}

Table 2. The Specification of Homeroom Teacher Table

\begin{tabular}{|c|l|l|c|c|c|}
\hline No & $\begin{array}{l}\text { Data } \\
\text { Element }\end{array}$ & Acronym & Type & Len & Info \\
\hline 1 & Teacher ID & teacher_id & char & 18 & $P K$ \\
\hline 2 & $\begin{array}{l}\text { Teacher } \\
\text { Name }\end{array}$ & teacher_name & varchar & 50 & \\
\hline
\end{tabular}

Source : (Research Results, 2019)

\section{Table of Student}

Table 3. The Specification of Student Table

\begin{tabular}{|c|l|l|c|c|c|}
\hline No & $\begin{array}{l}\text { Data } \\
\text { Element }\end{array}$ & Acronym & Type & Len & Info \\
\hline 1 & Student ID & student_id & char & 8 & $P K$ \\
\hline 2 & NISN & nisn & char & 15 & \\
\hline 3 & $\begin{array}{l}\text { Student } \\
\text { Name }\end{array}$ & student_name & varchar & 50 & \\
\hline 4 & Gender & gender & varchar & 9 & \\
\hline
\end{tabular}

\begin{tabular}{|c|l|l|c|c|c|}
\hline 5 & $\begin{array}{l}\text { Place Of } \\
\text { Birth }\end{array}$ & $\begin{array}{l}\text { place_of_birt } \\
\text { h }\end{array}$ & varchar & 35 & \\
\hline 6 & $\begin{array}{l}\text { Date Of } \\
\text { Birth }\end{array}$ & date_of_birth & date & 8 & \\
\hline 7 & Religion & religion & varchar & 10 & \\
\hline 8 & Address & address & varchar & 150 & \\
\hline 9 & $\begin{array}{l}\text { Student's } \\
\text { Status }\end{array}$ & student_status & varchar & 15 & \\
\hline 10 & $\begin{array}{l}\text { Father's } \\
\text { Name }\end{array}$ & father_name & varchar & 50 & \\
\hline 11 & $\begin{array}{l}\text { Father's } \\
\text { Education }\end{array}$ & $\begin{array}{l}\text { father_educati } \\
\text { on }\end{array}$ & varchar & 20 & \\
\hline 12 & $\begin{array}{l}\text { Father's } \\
\text { Occupation }\end{array}$ & $\begin{array}{l}\text { Father_occup } \\
\text { ation }\end{array}$ & varchar & 20 & \\
\hline 13 & $\begin{array}{l}\text { Mother's } \\
\text { Name }\end{array}$ & mother_name & varchar & 50 & \\
\hline 14 & $\begin{array}{l}\text { Mother's } \\
\text { Education }\end{array}$ & $\begin{array}{l}\text { mother_educa } \\
\text { tion }\end{array}$ & varchar & 20 & \\
\hline 15 & $\begin{array}{l}\text { Mother's } \\
\text { Occupation }\end{array}$ & $\begin{array}{l}\text { mother_occup } \\
\text { ation }\end{array}$ & varchar & 20 & \\
\hline 16 & Class Code & class_code & char & 4 & $F K$ \\
\hline
\end{tabular}

Source : (Research Results, 2019)

\section{Table of Report}

Table 4. The Specification of Report Table

\begin{tabular}{|c|l|l|c|c|c|}
\hline No & $\begin{array}{l}\text { Data } \\
\text { Element }\end{array}$ & Acronym & Type & Len & Info \\
\hline 1 & Report ID & report_id & char & 14 & $P K$ \\
\hline 2 & Semester & semester & varchar & 2 & \\
\hline 3 & $\begin{array}{l}\text { School } \\
\text { Year }\end{array}$ & school_year & varchar & 10 & \\
\hline 4 & Behavior & behavior & char & 1 & \\
\hline 5 & Diligence & diligence & char & 1 & \\
\hline 6 & Hygiene & hygiene & char & 1 & \\
\hline 7 & Sick & sick & int & 3 & \\
\hline 8 & Permit & permit & int & 3 & \\
\hline 9 & Alpha & alpha & int & 3 & \\
\hline 10 & total & total & int & 3 & \\
\hline 11 & Report Rate & report_rates & int & 3 & \\
\hline 12 & Student ID & student_id & char & 8 & FK \\
\hline Source &
\end{tabular}

Source : (Research Results, 2019)

\section{Table of Grade}

Table 5. The Specification of Grade Table

\begin{tabular}{|c|l|l|c|c|c|}
\hline No & $\begin{array}{l}\text { Data } \\
\text { Element }\end{array}$ & Acronym & Type & Len & Info \\
\hline 1 & $\begin{array}{l}\text { Subject } \\
\text { Name }\end{array}$ & subject_name & varchar & 50 & $P K$ \\
\hline 2 & Grades & grades & int & 3 & \\
\hline 3 & Rates & rates & double & 5.2 & \\
\hline 4 & Class Rates & class_rates & double & 5.2 & \\
\hline 5 & Report ID & report_id & char & 14 & $P K$ \\
\hline
\end{tabular}

Source : (Research Results, 2019) 
6. Table of Extracurricular

Table 6. The Specification of Extracurricular Table

\begin{tabular}{|c|l|l|c|c|c|}
\hline No & $\begin{array}{l}\text { Data } \\
\text { Element }\end{array}$ & Acronym & Type & Len & Info \\
\hline 1 & $\begin{array}{l}\text { Extracurr } \\
\text { icular } \\
\text { Name }\end{array}$ & excur_name & varchar & 25 & PK \\
\hline 2 & $\begin{array}{l}\text { Excur } \\
\text { Grades }\end{array}$ & excur_grades & Int & 3 & \\
\hline 3 & $\begin{array}{l}\text { Report } \\
\text { ID }\end{array}$ & report_id & Text & 14 & PK \\
\hline
\end{tabular}

Source : (Research Results, 2019)

\section{v. Conclusion ANd Suggestion}

\subsection{Conclusion}

Based on the results of the research that has been done, it can be concluded that the development of information systems of student grades can help overcome the problems that occur in Integrated Islamic Elementary Schools (SDIT). Administration Staff can manage the data of classes, homeroom, students and make reports quickly to the principal about the grades of SDIT students. Homeroom teachers can quickly and easily input the grades of students from the class they care for. Parents can obtain valid reports about the development of student learning achievements, and SDIT Principal can receive strategic information for learning evaluation materials and determine further policies in learning and teaching activities in schools.

The use of the SDIT student grades information system accelerates the student assessment process, so that the level of satisfaction of students, parents and SDIT Principal towards the presentation of the final results of the teaching and learning process is better than before.

\subsection{Suggestion}

In line with the results of research and development, the need for online publication of the grades of SDIT students is increasingly important. Parents of students can monitor the progress of their children's grades quickly and directly through the internet, even though they cannot go to school and meet with their child's homeroom teacher. Further research is suggested to discuss the development of the SDIT student value information system based online, in order to be able to complement the parents' needs for fast and accurate information and can be accessed online.

\section{REFERENCES}

Akhmad. (2016). Manajemen Sekolah Dasar Islam Terpadu. Jurnal Ilmu Pendidikan, 22(1), 1-8. https://doi.org/10.17977/JIP.V22I1.8638

Arikunto, S., \& Yuliana, L. (2008). Manajemen Pendidikan (1th ed.). Yogyakarta: Aditya Media.

Fathansyah. (2007). Buku Teks Komputer Basis Data (4th ed.). Bandung: Informatika.

Hoffer, J. A., Ramesh, V., \& Topi, H. (2011). Modern Database Management (10th ed.). New Jersey: Prentice Hall.

Mulyasa, E. (2011). Menjadi Kepala Sekolah Profesional (11th ed.). Bandung: PT Remaja Rosdakarya.

O'Brien, J. A. (2006). Pengantar Sistem Informasi: Perspektif Bisnis dan Manajerial (12th ed.). Jakarta: Salemba Empat.

Paryati, \& Murya, Y. (2008). Sistem Informasi. Yogyakarta: Penerbit Ardan Media.

Podungge, E. salim., \& Asmawati. (2017). Sistem Informasi Data Nilai Siswa Pada SMP Negeri 2 Bahodopi di Kabupaten Morowali. Jurnal Elektronik Sistem Informasi Dan Komputer, 3(1), 30-38. Retrieved from http://jesik.web.id/index.php/jesik/article/view $158 / 40$

Puspita, D., \& Yuliana, E. (2016). Perancangan Aplikasi Pengolahan Data Nilai Siswa Sekolah Dasar Negeri 1 Jaya Sakti Menggunakan Visual Basic. JPGMI, 2(1), 44-53.

Ramadan, R. (2018). Sistem Informasi Akademik Pada SMK Kesehatan VIA MEDIKA. Sinkron: Jurnal Dan Penelitian Teknik Informatika, 3(1), 153-158. Retrieved from https://jurnal.polgan.ac.id/index.php/sinkron/ar ticle/view/161

Sommerville, I. (2011). Software Engineering (9th ed.). Massachusetts: Addison-Wesley.

Winkel, W. S. (2009). Pisikologi Pengajaran (4th ed.). Jakarta: PT. Grasindo. 
Yasin, V. (2012). Rekayasa Perangkat Lunak Berorientasi Objek. Jakarta: Mitra Wacana Media.

Akhmad. (2016). Manajemen Sekolah Dasar Islam Terpadu. Jurnal Ilmu Pendidikan, 22(1), 1-8. https://doi.org/10.17977/JIP.V22I1.8638

Arikunto, S., \& Yuliana, L. (2008). Manajemen Pendidikan (1th ed.). Yogyakarta: Aditya Media.

Fathansyah. (2007). Buku Teks Komputer Basis Data (4th ed.). Bandung: Informatika.

Hoffer, J. A., Ramesh, V., \& Topi, H. (2011). Modern Database Management (10th ed.). New Jersey: Prentice Hall.

Mulyasa, E. (2011). Menjadi Kepala Sekolah Profesional (11th ed.). Bandung: PT Remaja Rosdakarya.

O’Brien, J. A. (2006). Pengantar Sistem Informasi: Perspektif Bisnis dan Manajerial (12th ed.). Jakarta: Salemba Empat.

Paryati, \& Murya, Y. (2008). Sistem Informasi. Yogyakarta: Penerbit Ardan Media.
Podungge, E. salim., \& Asmawati. (2017). Sistem Informasi Data Nilai Siswa Pada SMP Negeri 2 Bahodopi di Kabupaten Morowali. Jurnal Elektronik Sistem Informasi Dan Komputer, 3(1), 30-38. Retrieved from http://jesik.web.id/index.php/jesik/article/view $158 / 40$

Puspita, D., \& Yuliana, E. (2016). Perancangan Aplikasi Pengolahan Data Nilai Siswa Sekolah Dasar Negeri 1 Jaya Sakti Menggunakan Visual Basic. JPGMI, 2(1), 44-53.

Ramadan, R. (2018). Sistem Informasi Akademik Pada SMK Kesehatan VIA MEDIKA. Sinkron: Jurnal Dan Penelitian Teknik Informatika, 3(1), 153-158. Retrieved from https://jurnal.polgan.ac.id/index.php/sinkron/ar ticle/view/161

Sommerville, I. (2011). Software Engineering (9th ed.). Massachusetts: Addison-Wesley.

Winkel, W. S. (2009). Pisikologi Pengajaran (4th ed.). Jakarta: PT. Grasindo.

Yasin, V. (2012). Rekayasa Perangkat Lunak Berorientasi Objek. Jakarta: Mitra Wacana Media. 